2003

\title{
Mothers Who Kill: Cross-cultural Patterns in and Perspectives on Contemporary Maternal Filicide
}

Michelle Oberman

Santa Clara University School of Law, moberman@scu.edu

Follow this and additional works at: http://digitalcommons.law.scu.edu/facpubs

Part of the Law Commons

\section{Recommended Citation}

26 Int'l. J. L. and Psychriatry 493 (2003)

This Article is brought to you for free and open access by the Faculty Scholarship at Santa Clara Law Digital Commons. It has been accepted for inclusion in Faculty Publications by an authorized administrator of Santa Clara Law Digital Commons. For more information, please contact sculawlibrarian@gmail.com. 


\title{
Mothers who kill: Cross-cultural patterns in and perspectives on contemporary maternal filicide
}

\author{
Michelle Oberman* \\ Professor of Law, DePaul University College of Law, 25 East Jackson Boulevard, Chicago, IL 60604, USA
}

\begin{abstract}
"The eye sees only that which the mind is prepared to comprehend."-Henri Bergson ${ }^{1}$
To most contemporary minds, the thought of a mother killing her child evokes a deep sense of horror and outrage, as it represents a betrayal of the presumption of maternal love and altruism upon which much of civilization rests. Unsurprisingly, then, maternal filicide generally is regarded as a crime committed by "crazy" women. ${ }^{2}$ Upon close examination of the nature of maternal filicide across cultural, religious, and geographical lines in the early 21 st century, it is clear that this description falls far short of conveying the reality of maternal filicide. Although mental illness may be a baseline link among many of these cases, this is true only if one defines mental illness very broadly. A far more profound commonality linking contemporary cases emerges when one focuses on the perpetrator's life circumstances at the time of her act. At the most basic level, maternal filicide is a crime committed by mothers, against their own children, and therefore is, by definition, a reflection on the individual mother's experience of the conditions under which she was expected to raise her child.

By focusing on the circumstances surrounding the mother who kills her child, it becomes clear that maternal filicide is not a random, unpredictable crime committed predominantly
\end{abstract}

\footnotetext{
* Tel.: +1-312-362-8151; fax: +1-312-362-5448.

E-mail address: moberman@depaul.edu (M. Oberman).

${ }^{1}$ Henri Bergson, French philosopher and recipient of the Nobel Prize for Literature in 1927.

2 See Ania Wilczynski, Child Homicide 121 (1997). Wilzcynski's qualitative analysis found that filicidal women are "predominately viewed as 'sad' ('social casualties' who are acting irrationally in response to their difficult circumstances and/or inadequacy) or 'mad' (mentally disturbed)"; their "killings tend to be viewed as aberrant 'tragedies' for which they are not responsible." Granted, some filicidal women are mentally disturbed. See P.T. d'Orban, Women Who Kill their Children, 134 Brit. J. of Psych. 566, 566-577 (1979) (estimating 35/85 cases of filicidal women had a history of psychiatric illness).
} 
by mentally ill women. Instead, it is deeply imbedded in and responsive to the societies in which it occurs. As such, the circumstances that surround maternal filicide in different cultures vary widely. Nonetheless, a careful analysis of contemporary cases confirms one fundamental similarity: in virtually every instance, maternal filicide is committed by mothers who cannot parent their child under the circumstances dictated by their particular position in place and time.

This insight is crucial for those hoping to understand and to curtail the persistence of child abuse, generally, and of maternal filicide, in particular. The best way to protect children well may be to reevaluate societal norms governing motherhood and women's status, insuring that they are not generating unintended negative consequences in the form of harm to children.

Toward that end, this article presents a brief cross-cultural review of maternal filicide, focusing specifically on the varying circumstances that surround the mothers who commit this crime. My goal is not to provide a comprehensive map of contemporary maternal filicide, but rather, to illustrate the manner in which a society's structure of motherhood and women's status contributes to maternal filicide. Special attention will be paid to the unwritten norms that govern women and motherhood, as well as to the manner in which distinct societies understand, rationalize, and punish maternal filicide. The article begins with a review of the patterned nature of maternal filicide in the United States. I will then compare and contrast these patterns with those observed in three other countries, each with distinct socio-political realities that shape the mothering experience: India, Fiji, and Hungary. The article concludes with a section on the lessons and policy objectives that may be derived from this brief crosscultural survey.

\section{Contemporary United States illustrates this synergy: five categories}

I have been tracking U.S. maternal filicide cases since the early 1990s. My research has involved culling and sorting hundreds of contemporary accounts of maternal filicide from the media and legal databases, searching for the most thorough and detailed accounts of each case that I identify. Early on in this work, it was evident that the cases were strikingly patterned in nature, with certain sets of facts tending to repeat themselves in numerous cases. Others have noted the patterned nature of maternal filicide cases, and have offered up a variety of classification schemes. ${ }^{3}$ The categories I will be using are derived from both my own research, and from my more recent work with my co-author, psychologist Cheryl Meyer. After reviewing hundreds of cases of maternal filicide, we developed a typology that is predicated upon our belief that this crime is not merely about mental illness, but rather, arises out of the unique interaction of social, environmental, cultural, and individual variables. Our classification identifies five broad categories of contemporary U.S. maternal filicide cases,

\footnotetext{
3 See Cheryl Meyer and Michelle Oberman, Mothers Who Kill Their Children: Understanding the Acts of Moms from Susan Smith to the "Prom Mom" (2001) at 20-31 (summarizing the various typologies of maternal filicide cases).
} 
each of which may be viewed as responsive to the societal construction of and constraints upon mothering. ${ }^{4}$

\subsection{Neonaticide}

The first distinctive set of cases involves neonaticide, or the killing of one's offspring within the first 24 hours of life. These cases typically involve young women, from the widest variety of socio-economic, racial, and religious background, who deny the fact of their pregnancy, both to themselves and to others. Their denial is triggered at least in part by their belief that, were they to disclose their pregnancies, they would be completely cut off from their social support network. ${ }^{5}$ Almost always, the girls face their pregnancies alone, as their relationship with the man or boy who impregnated them ends often as soon as the pregnancy is discovered.

A variety of factors seem to inhibit the ability of these girls to resolve upon a course of action. First, there is a sense of fear, if not terror, surrounding the fact of pregnancy in these cases. These girls tend to be deeply ambivalent about their pregnancies. The pregnancy evokes terror, and yet, for reasons such as religion, culture, money, ambivalence, and immaturity, these girls are unable or unwilling to pursue the alternatives of abortion or adoption. In addition to the terror it evokes, however, the pregnancy represents a child, and a source of unconditional love. The uncertainty and isolation they feel leads these young women to dissociate from their changing bodies, living day to day, making no plans for the inevitable labor and delivery of their baby. So profoundly do these girls deny the inevitable birth of their child that they tend to mistake labor pains for a need to defecate, and the overwhelming majority of their babies are born while their mothers labor on the toilet. One of the more astounding facts about these cases is that the girls tend to endure labor and deliver in silence, perhaps bespeaking a profound level of fear, if not one of psychotic dissociation. Interestingly, subsequent psychiatric evaluation of these girls reveals that, even prior to pregnancy, many suffered from severe dissociative states associated with a history of early abuse and chaotic family life. ${ }^{6}$

The concrete reality of single parenthood raises an additional set of factors that may contribute to the inability of these girls to resolve upon a course of action. These girls seem to fear, perhaps reasonably, that, without a strong support network, they would be unable to afford to raise a child. ${ }^{7}$ Contemporary U.S. policies toward single parenting, public assistance, and day care help to explain the nature of these fears. Were they to attempt to parent on their own, these girls could expect little in the way of government assistance. They

\footnotetext{
${ }^{4}$ Michelle Oberman, Mothers Who Kill: Coming to Terms with Modern American Maternal filicide, 34 Am. Crim. L. Rev. 1, (1996), and Cheryl Meyer and Michelle Oberman, Mothers Who Kill Their Children: Understanding the Acts of Moms from Susan Smith to the "Prom Mom," (2001).

${ }^{5}$ Christine M. Alder and June Baker, Maternal Filicide: More than One Story to be Told, 9 Women and Crim. Just. 15, 28-31 (1997).

${ }^{6}$ Margaret G. Spinelli, Neonaticide: A Systematic Investigation of 17 Cases, in Maternal filicide:Psychological and Legal Perspectives on Mothers (2002) at 105, 110-111.

${ }^{7}$ See Denial of Pregnancy: Secret Lives, in Meyer and Oberman, supra note 3, at 41-50 for a summary of recent research on mothers who hide their pregnancies.
} 
would be required to secure a job within 2 years and are entitled to a lifetime maximum of 5 years of public assistance. ${ }^{8}$ If, as is often the case for those with limited formal education, they qualified only for minimum wage jobs, their salaries would scarcely cover the costs of housing and food, let alone day care expenses. ${ }^{9}$ In light of this, it is little wonder that the idea of parenting without a supportive family terrifies them.

Of course, many of the families from which these girls come would not have abandoned them due to their pregnancy. Nonetheless, these girls tend to be emotionally isolated from the adults in their lives, as evidenced by the fact that they elect to "conceal" their pregnancies from parents, family, teachers, and others. Upon closer examination, the adults in many of these cases ignored numerous warning signs and calls for help from the pregnant girls. ${ }^{10}$

\subsection{Fatal child neglect}

A second pattern among contemporary U.S. maternal filicide cases involves fatal child neglect. ${ }^{11}$ These cases are not intentional killings, but rather, occur when the mother, as primary caretaker, is distracted from or inattentive to her child's needs. For example, many contemporary cases involve babies who die when their mothers are taking care of other tasks - tasks that frequently are related to parenting. A common example is a baby who is left in the bathtub, or in the care of a still-young older sibling, while the mother is in the kitchen cooking. Occasionally, these neglect-related maternal filicide deaths occur when the mother is socializing and the child is left unattended in a home or a car.

It is worth noting that the mothers in these cases often are parenting under precisely the conditions feared by the women who commit neonaticide. The vast majority of these cases involve women who live alone, or whose partners are almost completely removed from the parenting process. Isolated and relatively poor, these women tend to be adequate, if not good parents. On rare occasions, however, they make bad parenting decisions, and some of these decisions have devastating consequences.

8 "Under TANF [Temporary Assistance for Needy Families is the program created by the Department of Health and Human Services by the Welfare Reform Act of 1996], parents or caretakers must engage in work (as defined by the State) when determined ready, or no later than 24 months, whichever is earlier." Work is required immediately upon receipt of benefits in 30 states, 8 allow recipients 6 months to find work, while 12 require work within 24 months. One state allows 30 months for recipients to find work, but only after they obtain a waiver. Office of Planning, Research and Evaluation, U.S. Department of Health and Human Services, Specific Provisions of TANF State Programs, (2002), available at http://www.acf.dhhs.gov/programs/opre/ar2001/chapter13.htm.

9 Philipe Levine and Diane M. Whitmore, Teen Motherhood, Labor Market Involvement, and the Receipt of Public Assistance: JCPR Working Paper 84, Joint Center for Poverty Research: Northwestern University/ University of Chicago (1999); See Welfare Recipients Struggle to Balance Work and Family, Poverty Research News, July-Aug. 2002, available at http://www.jcpr.org/newsletters/vol6_no4/index.html. See also Barbara Ehrenreich, Nickel and Dimed: On (Not) Getting by in America (2002) for a detailed description of one woman's (failed) attempt to make a decent living by diligently working low wage jobs in various American cities.

10 Oberman, Mothers Who Kill, supra note 4, at 55-57. For example, one pregnant teenager's cries for help included asking her mother if she thought she was getting fat, to which her mother responded by feeling the roundness of her belly before telling her she was fine.

11 Meyer and Oberman, supra note 3, at 37. 
In the past, these children's deaths might have been regarded as tragic accidents. In the contemporary United States, however, we treat them as homicides. This is a reflection of the social construction of motherhood, which is more than simply a full-time job. The unwritten rules that govern the role of mother require constant vigilance and altruism. To the extent that these child neglect cases occur when a mother is entertaining a male lover, or visiting a beauty parlor, society is merciless in its scorn and fury. ${ }^{12}$

\subsection{Abuse-related maternal filicide}

A third category of maternal filicide cases involves women who kill their children during an episode of violent abuse. Some of these cases reflect a single act of violence targeted at the child, but more often, these cases involve mothers who abuse their children with some regularity. The child's death is not actually intended, but rather, is the natural result of a long history of violence.

Although cases of chronic child abuse carry with them a unique horror, even among maternal filicide cases, it is important to note that there are regular, even predictable, patterns to these children's deaths. Indeed, epidemiologists have demonstrated the specific hours during each day when children are most at risk of death by homicide. ${ }^{13}$ They coincide with mealtimes and bedtimes; events that often are accompanied by stress, arguments, and the need to discipline even in stable, loving households. ${ }^{14}$ As such, one might observe that women who kill their children in abuse-related maternal filicides are affected by the demanding tasks associated with childcare. Seen from this angle, many of the abuse-related cases seem to involve mothers who lack the impulse control of their peers, but the impulse that motivated these killings is surprisingly commonplace.

\subsection{Assisted or coerced maternal filicide}

A fourth category of U.S. maternal filicide cases involves women who kill their children in conjunction with their male partners. These cases tend to reflect the overlapping problems of domestic violence and child abuse, as the great majority of these mothers

${ }^{12}$ For example, in the case of Jennie Bain Ducker, a young mother who was sentenced to 18 years after leaving her boys unattended in a vehicle for $8 \mathrm{~h}$ while she visited her boyfriend in a motel, even the judge was cited as saying, "Stolen moments with this man in this motel room were more important than her babies." Gerri Ferris, Mother Receives 18 Year Sentence for Sons' Death, Atlanta Journal and Constitution, Nov. 10, 1995, at 11C. See Jonathan Martin, CPS Details Child Neglect before Death, Spokane Spokesman Review, July 10, 2002 , at A1 (noting that mother was "willing to leave her daughter in unsafe conditions, including letting at least one sex offender baby-sit," without any mention of the mother's work schedule or support system alternatives in reporting of the death of a 2-year-old at the hands of a friend's boyfriend) (emphasis added), and Donald E. Coleman, Two Get Prison in Child's Death, Fresno Bee, July 17, 2002, at B1 (citing a social worker in reporting on the sentencing of a mother and her lover for the beating death of her child: "His mother failed to protect him and that's a mother's responsibility.").

${ }^{13}$ K. Chew, et al, Epidemiology of Child Homicide: California, 1981-1990, Homicide Studies, 1999, at $78-85$.

14 Chew, supra note 13. 
are intimately involved with violent and abusive partners. ${ }^{15}$ Most of these mothers fail to intervene to protect their child from harm at the hands of their male partner. On occasion, however, the mother also harms the child. In recent years, the U.S. criminal justice system has charged these women with homicide, claiming that the failure to protect a child is tantamount to an affirmative act of harm. Of course, much of what is known about battered women would suggest that these women are themselves caught in the cycle of an abusive relationship, and are unable to act to protect themselves or their children. ${ }^{16}$ Instead of reflecting mental illness or apathy, these cases generally arise out of a battered woman's fear of being required to manage alone, as a mother with children, with limited economic and social supports. Ironically, in these cases, we once again find mothers who may be paralyzed by the same structural fears that plague the girls who commit neonaticide.

\subsection{Purposeful maternal filicide}

The final category of maternal filicide cases is distinct from the others in that it involves women who purposely killed their children. In addition, virtually all of the cases in this final category involve mothers who manifested some degree of mental illness. But what is critical to note about these cases is that it is not simply the mother's mental illness that leads to the child's death. Instead, it is the combination of the mother's illness and her relative isolation as her child's primary caretaker that contributes to the child's death.

For instance, consider the situation of women who suffer from severe mental illness, whether acute or chronic, and are attempting to fulfill the many obligations tied to being a full-time primary caretaker for their children. A significant depressive or psychotic episode almost by definition inhibits a mother's capacity for meeting the intense emotional, physical, and psychological demands of her young children. Likewise, a woman who suffers from a chronic mental impairment may be constitutionally incapable of meeting the demands of parenting in isolation, without external support.

There are numerous maternal filicide cases involving severely ill women who were expected to care for their children, without any outside support, for extended hours. Perhaps the best known example of this is the case of Andrea Yates, a suicidal woman who was hospitalized with postpartum psychosis and depression on several occasions, the last of which was 1 month before she drowned her five children. ${ }^{17}$ Even though she acknowledged both to her doctors and to her family her ongoing thoughts of suicide, she felt pressed to return to her family. She left the hospital, and resumed her life as a mother: home-schooling her elder four children while caring for her newborn baby, attending to her frail mother, and mourning the death of her father from Alzheimer's disease. Her husband worked long hours as an engineer, and did not allow “outside babysitters." Yates' only respite was an occasional visit from her

\footnotetext{
15 Cheryl Meyer and Margaret G. Spinelli, Medical and Legal Dilemmas of Postpartum Psychiatric Disorders, in Maternal filicide: Psychological and Legal Perspectives on Mothers (Margaret G. Spinelli ed., 2002).

16 See generally, Lenore Walker, The Battered Woman (1979).

17 Megan K. Stack, Russell Yates Tells of a Loving Wife, L.A. Times, Feb. 28, 2002, at A19.
} 
mother-in-law. Although it may be accurate to blame her children's deaths on Ms. Yates' mental illness, a more precise conclusion would note that these deaths would not have occurred but for the fact that Yates was expected to parent in isolation, without external support. $^{18}$

\subsection{U.S. response to maternal filicide}

There is little doubt that mothers who kill their children should be held accountable for their actions. One of the central moral challenges of these cases lies in determining the appropriate level of accountability to attribute to these women. Many nations around the world have specific maternal filicide statutes, which recognize the extent to which this crime is distinct from ordinary maternal filicide, and explicitly diminish the severity of punishment for women who kill their children. ${ }^{19}$ U.S. jurisdictions lack such statutes, and maternal filicide is prosecuted under the standard homicide laws. The result has been a tendency toward treating each maternal filicide case as exceptional, rather than recognizing the patterns that link these cases, as well as the extent to which these crimes are linked to social expectations for mothers. Often, the media seems to play a powerful role in dictating the defendant's blameworthiness, and even in determining the resolution of these cases. $^{20}$

The result is that U.S. maternal filicide case law is incoherent and often arbitrary. Women convicted of substantially equivalent crimes, such as neonaticide, receive sentences that vary from probation with counseling to life imprisonment. ${ }^{21}$ As I have concluded elsewhere, the inconsistencies seen in the U.S. criminal justice system's response to cases involving maternal filicide is disturbing not only for reasons of the potential for injustice in individual cases, but also because the drama surrounding the U.S. tendency to "over prosecute" and "under convict" tends to eclipse the broader patterns in these cases, thereby limiting the potential to

18 Anne Taylor Fleming, Ideas and Trends: Crime and Motherhood; Maternal Madness, N.Y. Times, Mar. 17, 2002, $\S 4$ at 3. Ms. Yates is currently serving a life sentence for capital murder in a Texas prison. Carol Christian and Lisa Teachey, DA Closes Yates Case-for now; Husband Won't Face Charges in Drowning, Houston Chronicle, June 15, 2002, at A33.

19 See, e.g. the British Maternal Filicide Act, which provides: "Where a woman by any act or omission causes the death of her child being a child under the age of twelve months, but at the time of the act or omission the balance of her mind was disturbed by reason of her not having fully recovered from giving birth to the child or by reason of the effect of lactation consequent upon the birth of the child, then, notwithstanding that the circumstances were such that but for this Act the offense would have amounted to murder, she shall be guilty of felony, to wit, maternal filicide, and may for such offence be dealt with and punished as if she had been guilty of the offence of manslaughter of the child." Maternal Filicide Act, 1982, c. 48 (Eng.). While manslaughter is punishable by life imprisonment in England, the practical impact is that many women convicted under the act receive lenient, probationary sentences. For a discussion of the origins and applicability of this act, and of acts like it, see Oberman, Mothers Who Kill, supra note 4, at 18. Other countries with similar acts include Australia, Austria, Canada, Germany, and New Zealand. Velma Dobson and Bruce Sales, The Science of Maternal Filicide and Mental Illness, 6 Psychol., Pub. Pol'y, and Law 1098, 1099 (2002).

${ }^{20}$ Meyer and Oberman, supra note 3, at 46, 58-60.

21 Oberman, Mothers Who Kill, supra note 4, at 26. 
articulate effective modes of preventing this crime. ${ }^{22}$ Plainly, the United States would be better served by adopting some mechanism to standardize the resolution of these cases.

\section{Other cultures, other patterns}

By all accounts, there is evidence of maternal filicide in virtually every known culture throughout human history. ${ }^{23}$ Nonetheless, the study of maternal filicide is enormously challenging, due to the varying extent to which societies perceive and acknowledge the problem of maternal filicide. A central problem with studying maternal filicide in virtually any society, including the United States, is the lack of literature. ${ }^{24}$ In most countries, the issue of maternal filicide simply is not on the proverbial radar screen, and scholars ranging from anthropologists to physicians are strikingly unaware of the persistence of this phenomenon. As a result, research into this subject can be tedious and time-consuming.

Even in those societies in which there is an awareness of maternal filicide, such awareness often is limited to one particular variety of maternal filicide. For instance, there are many demographic studies of maternal filicide in contemporary India and China, evidencing patterns of female neonaticide. ${ }^{25}$ To be sure, in nations of such size and complexity, there must be other forms of maternal filicide that occur. There, as elsewhere, some mothers must develop postpartum psychosis and kill their children. There, as elsewhere, some mothers must physically abuse their children, or refrain from interfering in their partner's violent treatment of their children. But, as Henri Bergson observed, "The eye sees only that which it is prepared to comprehend," and outside of a handful of Western societies, few have undertaken to document the subtle patterns in maternal filicide cases, and fewer still, the more complex problems underlying this crime. ${ }^{26}$

22 Id., at $77-89$.

23 K.L. Moseley, The History of Maternal Filicide in Western Society, 1 Issues in Law and Medicide, 345 at 346-357 (1986).

${ }^{24}$ N. Prabha Unnithan, Children as Victims of Homicide: Part I-Historical and Anthropological Research, Crim. Just. Abstracts 146 (Mar. 1991). But see Mensah Adinkrah, When Parents Kill: An Analysis of Filicides in Fiji, Int'1 J. of Offender Therapy and Comp. Criminology, April 2001, at 144 (positing that while much has been published regarding maternal filicide in Western societies, little has been published regarding small, non-Western societies, thus making cross-cultural understandings of maternal filicide as a behavioral phenomenon difficult).

25 See Celeste McGovern, Chinese Puzzle: 117 Boys for 100 Girls, Report, June 10, 2002 (Newsmagazine), at 56 (attributing China's 2000 Census figures to the Chinese government's one-child policy: “an effort that includes forced abortions, involuntary sterilization, the occasional drowning of an unregistered newborn in a rice paddy, and imprisonment of dissidents."). See also Luise Cardarelli, The Lost Girls, Utne Reader, May/June 1996, 13, Renu Dube, Women Without Choice: Female Maternal filicide and the Rhetoric of Overpopulation in Postcolonial India, Women's Stud. Q., Spring/Summer 1999, 173, and Peter D. Toon, Daughters, Doctors and Death, Brit. Med. J., Oct. 1993, 875.

26 Ania Wilczynski, Child Homicide 69-74 (1997) (identifying demographic features of child homicide offenders in England and Australia). See Dobson and Sales, supra note 19, at 1102-1105 for a summary of historical demographic studies of maternal filicide in Australia, Canada, England, and the United States. It is only in recent years that scholars have moved beyond demographic studies to more qualitative efforts at documenting and understanding maternal filicide. 
Because my goal for this essay is to illuminate the manner in which cultural norms surrounding motherhood and the status of women shape the crime of maternal filicide, I have selected several societies to help me illustrate this point. My research was limited by the small number of countries from which I was able to gather even a minimum of information, and by my desire to evaluate cultures that stood as fairly dramatic contrasts with one another. Toward that end, I begin this section with a brief discussion of maternal filicide in contemporary India, which has a rich demographic literature regarding maternal filicide; a literature that reveals markedly distinct patterns from those seen in the United States, and in the West, generally. In addition, I was able to identify both scholarly work and a number of contemporary maternal filicide cases from Fiji, which makes a fascinating contrast to India, due to the fact that almost half of its population originates from India (Indo-Fijians), while the remaining half is either indigenous or from other cultures. Finally, the nation of Hungary, a relatively poor emerging democracy, provides yet another contrast to the nations considered. Although there is scarcely any scholarship on maternal filicide as it arises in Hungary, newspaper articles provide ample evidence both of the relatively common nature of the crime, and of the societal response to it.

\subsection{Patterns in contemporary maternal filicide in India}

In order to understand maternal filicide in India, and for that matter in much of Southeast Asia, one must begin by considering the entrenched phenomenon of son-preference. There is ample demographic evidence of son-preference in modern India, which manifests itself in a deeply skewed sex ratio. Actually, the distorted sex ratio problem is common throughout the Central Asian Republics, China, and South Asia. ${ }^{27}$ In developed countries, with adequate health care and nutrition, the sex ratio is approximately 1050 women to 1000 men. This statistic reflects the well-known fact of women's stronger survival advantages both biologically and culturally within postindustrial capitalist and socialist cultures. In India, the sex ratio is inverted, and there are fewer women than men. Indeed, the sex ratio is declining in recent years, dropping from $945 / 1000$ in 1991 to $927 / 1000$ in $2001 .{ }^{28}$ In light of the biological survival advantages for females, the only explanation for a sex ratio that favors males is social intervention. ${ }^{29}$

Sex ratios are not constant across India, but instead vary dramatically, with the lowest counts for females emerging in the poorest states in the north of the country. As of 1991, the sex ratios in that region averaged under 900 , with a subset of states showing a sex ratio of 774

27 Barbara Harriss-White, Gender-Cleansing: the Paradox of Development and Deteriorating Female Life Chances in Tamilnadu, in Signposts: Gender Issues in Post-Independence India 125, 127 (Rajeswari Sunder Rajan ed., 1999).

28 India's Female Freefall, CNN.com, available at http://europe.cnn.com/2001/WORLD/asiapcf/south/06/19/ india.ultrasound.

${ }^{29}$ Harriss-White, supra note 27, at 127. 
among children ages 5-9. By contrast, some southern Indian states, such as Kerela, have sex ratios close to parity. ${ }^{30}$

Although everyone agrees that this distorted sex ratio is not a natural phenomenon, there is widespread controversy over the source and the underlying causes of the problem of missing females. It is clear that the excess female child mortality is attributable to several factors: female maternal filicide, prenatal screening and the sex-selective abortion of female fetuses, and the neglect of the nutritional and health care needs of girl children. ${ }^{31}$ Indeed, it seems likely that prenatal screening is responsible for an increasingly large share of the sex ratio problem. ${ }^{32}$ Prenatal screening for purposes of sex selection began in India in the $1970 \mathrm{~s}$, with the costly and relatively invasive practice of amniocentisis. In the 1980s, the cheaper technique of ultrasound was introduced, and middle and working class Indian families joined the upper class in the practice of terminating unwanted female fetuses. ${ }^{33}$

That Indian abortions are sex-selective is undisputed. UNICEF notes a 1984 report from Bombay, which found that, of 8000 fetuses aborted following prenatal screening, 7999 were female. ${ }^{34}$ Estimates of the extent of this practice are difficult to obtain, but there is ample reason to believe that it is enormous in scope. One source estimated that over 3000 female fetuses are aborted every day in India. ${ }^{35}$ Given that the term maternal filicide presupposes the live birth of a child, sex-selective abortion, while morally reprehensible, does not actually constitute the killing of a child. (Unless one is of the position that fetuses are children, which then triggers the broader issue of abortion as maternal filicide - a debate that is well beyond the scope of this article.) Nonetheless, the widespread practice of sexselective abortion of female fetuses indicates a deep cultural bias against female offspring, which also emerges in the Indian practices of female maternal filicide both at birth and through neglect.

${ }^{30}$ Harriss-White, supra note 27, at 128.

31 Sabu M. George, Female Maternal filicide in Tamil Nadu, India-From Recognition Back to Denial? Reprod. Health Matters, 124, 124 (1997).

32 India's Female Freefall, supra note 28. ("The ultrasound scans, and the abortions that inevitably follow, lie behind the single most worrying statistic in India's 2001 census — a dramatic drop in the number of girls.").

33 S. Sudha and S. Irudaya Rajan, Female Demographic Disadvantage and Female Maternal Filicide, 30 Dev. and Change, July 1999, at 585-618. Mobile ultrasound units now travel to small towns and doctors offer immediate abortions after the tests. Landless laborers and farmers pay high interest rates for loans to pay for the test, as they do not see the high cost as a barrier. The slogan "Better Rs. 500 today than Rs. 50,000 tomorrow" illustrates this mentality.

${ }^{34}$ Zeng Yi et al., Causes and Implications of the Recent Increase in the Reported Sex Ratio at Birth in China, 19 Population and Dev. Rev., June 1993, at 297.

35 V.G. Julie Rajan, Will India's Ban on Prenatal Sex Determination Slow Abortion of Girls? Hinduism Today, available at http://www.hinduwomen.org/issues/maternalfilicide.htm (citing ABC News: Primetime Live (ABC television broadcast, Jan. 6, 1994)). Under pressure from women's groups and other NGOs, the Indian government has attempted to stop this practice by banning sex-selective abortion, and fining both health care providers and families who obtain this procedure. There is such strong public support of these tests, however, that even advocates of these laws agree that the only effect will be to drive the procedures underground. Not only are the laws regulating the procedure ripe with loopholes, parents afraid of detection use new methods of killing their children and guilty parents may bribe village officials to avoid punishment. See Sudha and Rajan, supra note 33 . 
For centuries in India, female infants have been murdered at birth, although the actual practices surrounding female maternal filicide have not been well documented. Several scholars have described a version of neonaticide virtually unheard of in the United Statesspecifically, one in which the newborn is killed by women other than the baby's mother. One Indian current affairs magazine described a thriving practice among midwives, who charge an additional rate for killing female offspring, after having assisted the mother in giving birth. ${ }^{36}$ Other sources report that the killing may be carried out by a senior woman in the family, generally the paternal grandmother. ${ }^{37}$ In spite of these reports, it seems likely that birth mothers commit many Indian neonaticides. As Brother James, who runs Anbu Illam, an Indian home for abandoned children, explained, "The women are not to blame. They kill their children because that is what their husbands tell them to do. Without their marital status, they have little in this society - and they know it." 38 The methods by which mothers kill their newborns are, according to at least one source, remarkably similar throughout the country, and include the use of poisonous plants, inducing choking by feeding the baby rice in its husk and various forms of suffocation. ${ }^{39}$

It is difficult to ascertain the exact scope of the practice of neonaticide, due in part to widespread denial of the problem by the government. ${ }^{40}$ One 1995 study of newly delivered women in one district of the Tamil Nadu region found that of 1320 newly delivered women, the number of girls who died was three times that of boys. The number was even higher among girls born to women with other living daughters, but without a son. ${ }^{41}$ A striking study from a government hospital in Usilampatti, which primarily serves the low-caste Kallar community, illustrates perhaps the most notorious example of female maternal filicide in India today. On average, 1200 children are born to Kallar mothers at

36 Soma Wadhawa, Lambs to Slaughter, Outlook, Oct. 18, 1995, available at http://www.outlookindiahttp:// www.outlookindia.com/fullprint/asp.

37 George, supra note 31, at 3.

38 Mala Sen, Death by Fire: Sati, Dowry Death, and Female Maternal Filicide in Modern India 95 (2001).

39 George, supra note 31, at 2; Sen, supra note 38, at 80-81, 101-102. One form of suffocation widely used by less-experienced midwives involves placing the newborn in a clay pot and sealing the lid with fresh dough so no one has to see the baby die. Wadhawa, supra note 36.

40 George, supra note 31, at 4. See also Wadhawa, supra note 36. In Bahir, a caste-ridden state of India, over 160,000 female infants are killed every year. The police deny the existence of the practice; there is no paperwork even suggesting it happens. NGOs working to eradicate female maternal filicide do not use the police, or even report the incidences, due to fears of alienating the mothers and midwives they work with by turning 'informer'. Also, after an NGO partially funded by UNICEF released a report on maternal filicide estimating 163,200 female infants were killed every year in Bahir, the State Government would not even confirm its receipt of the report. While the state governments continue to deny the problem and neglect enforcement, the Central Government acknowledged the problem in 1994 with passage of the Prenatal Diagnostic Technique (Regulation and Prevention of Misuse) Act, which "states that determining and communicating the sex of a foetus [sic] is illegal; that genetic tests can be carried out only in registered facilities; and only offered to women who meet certain medical criteria, such as being over 35, having a family history of genetic disorders, etc." Suhda and Rajan, supra note 33 . See note 33 and accompanying text for further evidence of the Indian government's struggle to come to terms with maternal filicide.

41 George, supra note 31 , at 3. 
that hospital each year, of which approximately 600 are girls. Out of these, an estimated 570 die within days of birth. Hospital physicians attributed $80 \%$ of these deaths to maternal filicide. ${ }^{42}$

A more commonplace, but equally difficult to document method of maternal filicide is the chronic nutritional and medical neglect of girls. ${ }^{43}$ Such deaths are a direct reflection of the undervaluing of female offspring, and are motivated by precisely the same cultural pressures that contribute to maternal filicide. Many mothers refuse to breastfeed baby girls, and instead, feed them nothing but water until their death ensues. According to Professor Sunita Kishor, this practice reflects an explicitly economic calculation:

Scarce, life-sustaining resources will be disproportionately allocated to male children as long as the returns to this investment are perceived to be greater than returns to a comparable investment in females ... [T]o the extent that females are less likely than males to participate in income-generating activities and contribute to the family's material assets, their economic worth is diminished. ${ }^{44}$

\subsection{Motherhood and the underlying causes of female maternal filicide in India}

Although many sources agree that female maternal filicide is rising in India, there is little agreement as to the cause. Among the possible explanations are the following, "the low status of women, decreasing fertility and consequent intensification of son preference, spread of the practice of dowry across all caste groups, the green revolution and the resulting marginalisation [sic] of women in agriculture, and a shift of cash cropping." 45 Of these various hypotheses, only one is consistently cited by virtually all who study this topic - that of dowry.

Dowry stems from an early cultural tradition of gift-giving to the bride from her own family, for the purpose of providing her with some personal wealth upon her marriage. ${ }^{46}$ Over the course of the past 200 years, this tradition was merged with the concept of dowry, which entailed gift-giving from the bride's family to the groom's family at the time of marriage. According to S. Mohan, Justice of the Supreme Court in India from 1991 to 1994, this practice remains dominant throughout the nation, and is "prevalent both in the urban as well as in rural areas." 47 There is a direct link between the astronomical size of contemporary

\footnotetext{
42 Sen, supra note 38 , at 225.

43 George, supra note 31, at 2.

44 Sunita Kishor, May God Give Sons to All: Gender and Child Mortality in India, 58, Am. Soc. Rev., April 1992 247, 247-48. A 1995 National Family Health survey revealed that child mortality figures for female children were a staggering 43\% higher than for male children. Kalpana Sharma, Sugar and Spice?, The Hindu Sunday Magazine, Feb. 7, 1999.

45 George, supra note 31, at 3.

46 Rajeswari Sunder Rajan, Introduction, in Signposts: Gender Issues in Post-Independence India 1, 5-6 (Rajeswari Sunder Rajan ed., 1999).

47 Rajan, supra note 46, at 7.
} 
dowry gifts, particularly relative to the income level of most Indian households, and the practice of female maternal filicide. As one scholar puts it:

Having a daughter all comes down to one point: if one has a daughter, she must be married; to be married, a daughter must have a dowry; with each daughter and each dowry, the family wealth declines and family members live less well. Therefore, if a family is not wealthy, as is the case in most of India, it is more likely that parents would prefer to have sons who, even if they never marry, will not detract from the family wealth. $^{48}$

At first blush, maternal filicide in India seems completely unrelated to the crime of maternal filicide that occurs in the United States. The dowry system seems to drive the most obvious distinction from maternal filicide in the West: specifically, the sex-specific nature of the crime in India. ${ }^{49}$ As such, even patterned crimes like neonaticide look entirely different in India than they do in the United States. For instance, those who commit neonaticide in India do not conceal their pregnancies, nor are they single and isolated. Instead, they tend to be married, and not only are their families aware of their pregnancies, but they may be quite supportive of (or insistent upon) the decision to destroy an unwanted daughter. ${ }^{50}$ Upon second thought, however, there is a constant theme that underlies these seemingly disparate cases. Like their U.S. counterparts, Indian women who kill their children do so because they perceive a lack of any viable options. The majority of Indian women are destitute, poorly educated, and dependent upon their husbands and their husbands' families for shelter, food, and safety. The selective preference for son sis not a conscious choice they make, but rather, one that is dictated by their circumstances.

\subsubsection{Contemporary Fiji}

In 2001, Mensah Adinkrah, a scholar from the South Pacific nation of Fiji, undertook an empirical analysis of that nation's maternal filicide cases. Grounded in a comparison to existing literature, primarily from Western nations, the study provides an excellent window into the similarities and differences in Fiji's experience of maternal filicide.

Fijian demographics retain the imprint of British colonization. As Adinkrah notes, "The majority of Fiji Indians (43.7\% of the population) are descendants of indentured laborers who migrated from India during the early period of British colonialism (1887-1916) to labor on

\footnotetext{
48 Rajan, supra note 46 , at 8.

49 See Sen, supra note 38, at 100, quoting Father Vincent, of Claretian Home for Female Infants, regarding the government's new initiatives to save girl babies: "They have never tackled the root cause, which is the dowry system." See also India's Female Freefall, supra note 28 ("Dowry payment is the main reason for female foeticide.").

50 See Wadhawa, supra note 36, pinning the "sin" of sex-selective killings by midwives on the patriarch of the family. See also Sen, supra note 38, at 210-237 for the story of Karrapayee Kannan, the first woman in India to be sentenced to life in prison for committing maternal filicide.
} 
sugarcane plantations." 51 Adinkrah notes that the society is "socially, economically, and politically segmented along racial and ethnic lines," with the result that subcultures retain distinctive languages, norms, and identities.

The majority of Fijians of all backgrounds (approximately 70\%) live in rural settings, where unemployment is a major problem. ${ }^{52}$ As is common in developing nations, the birth rate is high, and children constitute a high proportion of the total population. The pressures toward childbearing are numerous. Access to family planning services is limited and uneven, and abortion is illegal and is punishable with a 14-year prison sentence for both provider and recipient. ${ }^{53}$ Illegal abortions, when available, cost US\$600 to US\$800 - an amount that is completely unobtainable by the vast majority of young, poor women in the country. ${ }^{54} \mathrm{~A}$ study of five abortion trials in Fiji in the 1990s demonstrates that, although acquittal is quite common, the courts and the media regard these trials as an opportunity to interrogate and humiliate the woman who has obtained an abortion. ${ }^{55}$

In addition to these practical limitations on Fijian women's control over when and whether to conceive, there are severe social sanctions placed on those who conceive out of wedlock: "Nonmarital births are highly stigmatized; unwed mothers must confront the shame, anxiety, and guilt associated with premarital coitus, conception and parturition." 56 Finally, outside agencies such as the U.S. government report that both Fijian and Fiji Indian women function primarily in traditional roles, and are grossly underrepresented in government. ${ }^{57}$

Adinkrah's study traces all maternal filicide cases listed in the official Fijian homicide logbook between January 1, 1982 and December 31, 1994. ${ }^{58}$ These reports were corroborated with interviews and media accounts, which tended to be more extensive than police records. Of the 361 homicides that occurred during that time frame, 50 involved parent-child killings. Consistent with other nations' findings, a majority of these cases (36) consisted of mothers acting alone. As this article addresses the phenomenon of mothers who kill, I will focus on these 36 cases.

In Adinkrah's study of cases between 1982 and 1994, maternal filicide was equally common among Fijian and Fiji Indian mothers. There was a common pattern of economic vulnerability among the women, with only 3 or the 36 mothers employed outside of the home. Of the 36 cases committed by women, a full 21 involved neonaticide. ${ }^{59}$ As in the United States, the majority of neonaticidal mothers concealed their pregnancies from friends

\footnotetext{
51 Adinkrah, supra note 24, at 147.

52 Adinkrah, supra note 24, at 147.

53 Adinkrah, supra note 24 , at 148.

54 Adinkrah, supra note 24, at 149.

55 Mridula Shameem Sainath, Abortion Trials in Fiji: No Protection for Women, Reproductive Health Matters, 1993 , at 116 .

56 Adinkrah, supra note 24, at 144.

57 Bureau of Democracy, Human Rights and Labor, U.S. Department of State, Country Reports on Human Rights Practices-2001-Fiji (2002), available at http:/www.state.gov/g/drl/rls/hrrpt/2001/eap/8308pf.htm [hereinafter Country Report-Fiji].

58 Adinkrah, supra note 24, at 144.

59 Adinkrah, supra note 24 , at 146.
} 
and family, and gave birth unattended. Also consistent with patterns elsewhere, these mothers tended to be young and single, and either lacked the financial means to support the child, or sought to avoid the stigma of a nonmarital child. In more recent articles on the subject, local advocates point to poverty as the main cause of abandoned infants. ${ }^{60}$

Perhaps most surprisingly, given the high proportion of Fiji Indians in the population, there was little evidence of gender-specific maternal filicide. Only one case fits the contemporary Indian pattern. It involved a Fiji Indian mother who killed her daughter in the hospital, claiming that her husband had forewarned her "not to return from the hospital in the event that the baby was a female."61 As Fiji Indians no longer fully embrace the rigidity of the dowry system so prevalent in their native culture, the absence of sex-specific maternal filicide may be the best available evidence to support the notion that dowry holds the key to India's female maternal filicide problem. ${ }^{62}$ The non-neonaticide cases in Fiji demonstrate evidence of two of the patterns seen in U.S. cases. First, there are numerous cases in which women purposefully kill their children. Unlike in the United States, where these cases tended to reflect a degree of mental illness, the Fijian cases seem responsive to a high degree of interspousal conflict. Eight of the 36 cases (or 8 of 15 non-neonaticide cases) involved women whose lives were dominated by chronic marital violence, and who killed their children "in response to specific instances of abusive treatment at the hands of husbands or in-laws, then attempted or successfully committed suicide."63 Adinkrah's research revealed that these mothers had determined to take their own lives, but feared for the children's wellbeing in the event of their demise. There was also evidence of at least one instance of fatal child abuse by a mother, although the case seemed to involve a one-time effort to stop a child's crying, rather than chronic abuse. ${ }^{64}$

Although it is dangerous to draw too many conclusions from such a distance, and with so little evidence, several observations may be made. First, in Fiji, as elsewhere, neonaticide is responsive to cultural, as well as familial, perspectives on nonmarital sexuality and childbearing. The fact that neonaticide comprises a greater proportion of maternal filicides in Fiji $(58 \%)$ than in the Unites States likely reflects that culture's more stringent restrictions on women's sexuality. Interestingly, when one examines neonaticide as a proportion of all U.S. maternal filicide cases historically, particularly in an era in which there were similar barriers

${ }^{60}$ See Poverty Main Cause of Abandoned Babies: WCC, Village News, July 17, 2002 (Fiji's Women's Crisis Center cites poverty and "poor social attitude" as the major contributing factors to the rising number of maternal filicides in Fiji), and Temo Lenati, Fifth Foetus Found in Tank, Fiji Times, Aug. 13, 2002 ("Fiji Women's Crisis Centre co-ordinator Shamima Ali said as long as there was poverty, such crimes would persist.").

61 Adinkrah, supra note 24, at 148.

62 But see Phil Mercer, U.S. Highlights Fiji Bride-burning, BBC News, March 11, 2002, available at http:// news.bbc.co.uk/1/hi/world/asia-pacific/1866164.stm (positing that dowry is still practiced among Fiji Indians). Moreover, Adinkrah notes the persistent evidence of son-preference, if not in gender-specific maternal filicide, then at least in the differential treatment of boy and girl children, tracing the attitude to the Hindu practice of dowry. Adinkrah, supra note 24, at 154.

63 Adinkrah, supra note 24 , at 149.

64 There were numerous cases of fatal child abuse in the sample, mostly committed by fathers. Adinkrah attributes this to a society that commonly tolerates corporal punishment against children. Adinkrah, supra note 24 , at 149 . 
to contraception, abortion, and single parenting, one finds similar results. In a study of all Chicago maternal filicide between the years 1870 and 1930 , a full $70 \%$ of the infant deaths were neonaticides. ${ }^{65}$

Also, it is worth noting the pattern of relative lenience in the punishment of neonaticide in Fiji. Adinkrah's study finds that $25 \%$ of the women convicted of neonaticide received probationary sentences, and that the sentences of those who were incarcerated ranged from 6 to 18 months. This result is largely due to the fact that Fiji has a specific statute governing maternal filicide, drawn from the British model, and permitting maternal filicide to be treated as manslaughter, rather than as murder. ${ }^{66}$ This lenient pattern is familiar to those who have studied the history of neonaticide. Throughout history, societies that have had very restrictive norms governing nonmarital sex, contraception, abortion, and single parenthood have responded to neonaticide cases with a sense of mercy. British historians of the 18th and 19th centuries note that "courts regularly returned verdicts of not guilty despite overwhelming evidence to the contrary." 67 One study of French maternal filicide cases during this same era concluded that "many of the accused women were acquitted because the jurors felt that it was unfair that the females alone should bear the responsibility for the crimes." 68

A second observation that may be made about the Fiji cases arises from the striking number of cases involving domestic violence. Here one sees a new variation on the same point made in earlier sections - that maternal filicide is responsive to the structure of motherhood. There are several indications that domestic violence is commonplace in Fiji. The U.S. government's country report estimates that $10 \%$ of all women are abused. ${ }^{69}$ In a traditional society, in which "childbearing is considered a critical measure of womanhood," and most mothers work as full-time primary care givers within the domestic sphere, domestic violence is a relentless menace. To the extent that it goes unpunished, the crime of domestic violence may leave a mother wholly without recourse to safety. As a result, it is unsurprising to see that a relatively high proportion of maternal filicide cases in Fiji are suicide-

${ }^{65}$ Michelle Oberman, Understanding Maternal filicide in Context: Mothers who Kill, 1870-1930 and Today, 92 J. of Crim. L. and Criminology (2002). (Publication pending, Spring, 2003).

66 Section 205 of the Fiji Penal Code provides, "where a woman by any willful act or omission causes the death of her child being a child under the age of twelve months, but at the time of the act or omission the balance of her mind was disturbed by reason of her not having fully recovered from the effect of giving birth to the child or by reason of the effect of lactation consequent upon the birth of the child, then, notwithstanding that the circumstances were such that but for the provision of this section the offence would have amounted to murder, she shall be guilty of felony, to wit, maternal filicide, and may for such offence be dealt with and punished as if she had been guilty of manslaughter of the child." U.N. GOAR Comm. on the Rights of the Child, Addendum: Fiji, U.N. Doc CRC/C/28/Add.7 (1996).

${ }^{67}$ Constance B. Backhouse, Desperate Women and Compassionate Courts: Maternal Filicide in Nineteenth Century Canada, 1984 U. Toronto L. J. 447, 449. Resistance to convicting these women of murder remains commonplace today. See Oberman, Mothers Who Kill, supra note 4, at 26-31.

68 James M. Donovan, Maternal Filicide and the Juries in France, 1825-1913, 16 J. Fam. Hist. 157,169 (1991).

${ }^{69}$ Country Report-Fiji, supra note 57. Also see WCC Claims 40\% of Women are Raped by their Husbands, Fiji Villager, Aug. 19, 2002 (attributing high rates of marital rape to pervasiveness of domestic violence). 
homicides, or attempt suicide-homicides, committed by mothers who simply could not bear the violence in their lives.

One final observation about the Fiji cases is the absence of neglect-related maternal filicide. None of the cases reflected a pattern that is commonplace in the West - that of the child killed by an inattentive, distracted parent. There are at least two possible explanations for this. First, and most probable, these cases may arise, but the Fijian criminal justice system may not consider them to be homicides, and as such, the criminal justice system does not prosecute these mothers. Adinkrah's data are drawn from the "Murder and Manslaughter Register" of the Fiji police force. ${ }^{70}$ If these cases were not considered manslaughter, then they would not be listed in this record. Some support for this is seen in newspaper articles covering such stories. For instance, a June 2002 story tells of "another baby" who died because her parents failed to seek medical care. The story involved a 1-month-old infant whom police say was suffering from flu prior to her death. There is no indication that criminal charges were filed in the case. ${ }^{71}$

Indeed, there is little reason to believe that most nations regard neglect-related maternal filicides as criminal acts. Even in the United States, there is evidence that this was not always the case. ${ }^{72}$ There is an important significance inherent in the willingness of a society to judge a mother's inattentiveness as a criminal act, meriting prosecution for manslaughter. This speaks to the issue of the unwritten norms governing motherhood, revealing that, at least in the United States, motherhood is more than simply a full-time job-it is one's overriding obligation, overtaking all other desires or duties.

This distinction is related to the second possible reason for the absence of neglect cases from the Fijian maternal filicide cases - specifically, that Fijian mothers rear their children in a markedly different cultural context from that experienced by women in the United States. For better or worse, both Fijian and Fijian-Indian women parent within a family context that is likely to include other adults. This means less privacy for the mothers, and it may open them to varying forms of in-law pressures, but it also means that there generally is at least one person in addition to the mother who is on hand to protect a child from accidental harm. ${ }^{73}$

Fijian cases of maternal filicide, so distinct from those seen in the United States or in India, speak to the desperation of women unable to control their sexuality or reproduction. Relatively high rates of neonaticide seem to hearken back to a bygone era for most Western nations. And yet, it is apparent that Fiji's experience of maternal filicide, like that of the United States and India, is responsive to the status of women in that society. In this case, maternal filicide seems to be a reflection of women's relative powerlessness and the limited scope of their life options.

\footnotetext{
70 Adinkrah, When Parents Kill, supra note 24, at 147.

71 Parental Negligence Kills Baby, Village News, June 1, 2002.

72 Oberman, Understanding Maternal filicide in Context, supra note 65 (publication pending, Spring, 2003).

73 This is not to say that the presence of a spouse and/or additional family members always inhibits maternal filicide. Indeed, of the eight cases that Adinkrah documented where mothers killed their children in response to interspousal conflict, "the perpetrators were all Fiji Indian women experiencing chronic marital or domestic conflict and who killed their children in response to specific instances of abusive treatment at the hands of husbands or in-laws, then attempted or successfully committed suicide." Adinkrah, supra note 24, at 149.
} 


\subsubsection{Contemporary Hungary}

Unlike the other nations discussed in this essay, the Hungarian government is troubled by a declining birth rate, and has long maintained a number of explicitly pronatalist policies. These include maternity allowances, ${ }^{74}$ and laws that provide 24 weeks maternity leave and significantly limit an employer's right to terminate a woman in the months before and after having a child. ${ }^{75}$ Nonetheless, Hungary's population has been steadily declining since 1970 , and the most recent data indicate a negative growth rate of $-0.5 \%{ }^{76}$

Perhaps as a result of this concern, the problem of maternal filicide takes on an added urgency in Hungary. Police statistics show that, in Hungary, there is at least one child murdered by its mother every week. ${ }^{77}$ An estimated $50 \%$ of these cases involve newborns. ${ }^{78}$ Numerous sources suggest the problem of neonaticide and newborn infant abandonment is on the rise. ${ }^{79}$ Newborn babies, or their remains, are found in bushes, public parks, rubbish, sewers, and abandoned buildings. ${ }^{80}$ Official government statistics estimate that between 25 and 30 infants are murdered each year; unofficial estimates suggest that 10 times this number go undiscovered. $^{81}$ Local experts cite a number of factors behind this trend. First, the Hungarian health care system provides full coverage for most health care concerns, including prenatal care, labor, delivery, and after care. Beginning in 1994, however, the government introduced "austerity measures," one of which halted all funding of contraception. ${ }^{82}$ The average cost for a monthly cycle of contraceptive pills (the most widely used form of contraception) is US\$3.50, a cost that is exceedingly high for a country where the average monthly income for working women is US\$100. ${ }^{83}$ Commentators suggest that this cost is prohibitive for adolescents, $80 \%$ of whom are sexually active. According to Geda Szamosi, "Although a large percentage of young people have regular sexual relationships, most of them do not use any form of contraception. One tenth of abortion patients are aged 10 to

\footnotetext{
74 Katalin Koncz, Women's Studies in Hungary, Women's Stud. Q., 423, 425 (1996).

75 Women of the World-Laws and Policies Affecting their Reproductive Rights-East Central Europe 65 (Center for Reproductive Law and Policy ed., 2000) [hereinafter Women of the World]. Hungary's government also encourages married couples to raise more children by providing material benefits to families with three or more children; however, as Hungary's birth rate is predominately influenced by the economy, it is unlikely that current declines will change as a result of the proffered government support.

76 Women of the World, supra note 75 , at 58.

77 Geda Sazmosi, Getting Tough with a Delicate Problem, Budapest Sun, Jan. 28, 1999.

78 Sazmosi, supra note 77.

79 See Szamosi, supra note 77; Nigel Glass, Maternal Filicide in Hungary Faces Stiffer Penalties, Lancet, Feb. 13, 1999.

${ }^{80}$ Carl Kovac, Incubators in Hungarian Hospital Lobbies Allow Babies to be Abandoned more Safely, Brit. Med. J., July 24, 1999, 214; Glass, supra note 79.

${ }^{81}$ Glass, supra note 79. Hungary has a population of approximately 10.1 million. Bureau of Democracy, Human Rights and Labor, U.S. Department of State, Country Reports on Human Rights Practices-2001Hungary (2001), available at http:/www.state.gov/g/drl/rls/hrrpt/2001/eur/8264.htm [hereinafter Country Report-Hungary].

82 Sazmosi, supra note 77; Women of the World, supra note 75, at 62.

83 Beáta Pál, Unsolicited Advice, Budapest Sun, Mar. 2, 2000. While women in the financial sector do earn an average of $\$ 401$ per month, this data hardly seems liberating in light of the $\$ 672$ per month their male colleagues earn for the same job. Women of the World, supra note 75, at 66.
} 
14." ${ }^{84}$ The shockingly young age of this particular subgroup of abortion recipients may reflect the growing problem of child prostitution and sexual trafficking in Hungary. ${ }^{85}$

A second factor cited by experts in contributing to the rise in maternal filicide is the restrictive Hungarian abortion law. Before 1998, abortion was available more or less on demand. Over the course of the 1990s, debate over the legal status of abortion intensified, leading to a 1998 Constitutional Court decision that demanded that the Hungarian Parliament rewrite the abortion laws to provide the fetus with some protection. ${ }^{86}$ The new law provides that, in order to access a legal abortion, a woman must undergo mandatory medical counseling, designed to persuade her to continue her pregnancy. In addition, she must prove to a committee that she is in a "crisis situation." ${ }^{87}$ In addition, the government raised the cost of a legal abortion from US\$38 to US\$61 - clearly an extraordinary expense for a woman living on US\$100/month, let alone for an adolescent schoolgirl. ${ }^{88}$

The Hungarian government is aware of the increase in maternal filicide, and has taken action to counter the problem. Whereas the law formerly mirrored the British maternal filicide statute, and provided a maximum incarceration of 2 years for a mother who killed her infant, starting in March 1999, the penalty was raised from a minimum of 2 years in prison to a maximum of 8 years. ${ }^{89}$ Few seem convinced that tougher penalties will solve the problem of maternal filicide. ${ }^{90}$ The Budapest Sun ran an editorial in which urged the government to supply good sex education and subsidized contraceptives, rather than "[s]imply forcing mothers to deal with unwanted pregnancies which become unwanted babies...."91

Although the commentators do not mention it as often as the other factors thought to contribute to maternal filicide, the crime may take shape against a backdrop of economic desperation. ${ }^{92}$ Women's options with regard to childbearing may be shaped by economic realities, not only in terms of their ability to afford contraception or abortion, but more importantly, in terms of their ability to secure employment and housing. Both in the workplace and at home, Hungarian women are vulnerable to exploitation. A 1995 UN report

84 Sazmosi, supra note 77.

85 See Child Protection: Sexual Exploitation of Children, at http://www.seekjustice.org. (Last visited on 2/06/ 03) (noting "an enormous increase in child prostitution" in Hungary, where the average age of a child exploited in the commercial sex trade is 14 years).

86 Women of the World, supra note 75 , at 60.

87 Beáta Pál, supra note 83; Women of the World, supra note 76, at 60. To date, Parliament has not defined "crisis situation," but the law stipulates very narrow conditions under which an abortion will be medically indicated.

88 Beáta Pál, supra note 83.

89 Sazmosi, supra note 77.

90 See Sazmosi, supra note 77.

91 Editorial, The Art of Tough Governing, Budapest Sun, Jan. 28, 1999. Eight Hungarian hospitals in five cities have initiated their own efforts at stemming the tide of neonaticide and infant abandonment. They have placed incubators near their entrances, where mothers can surrender their newborns without questioning. These hospitals report having recovered a small number of infants. Kovac, supra note 80.

92 Secrecy Begets Tragedy in Hungary, Pro-Life E-News Canada, Nov. 20, 1996, available at http:// www.all.org/communique/cq961220.htm. ("The reason most often given for these killings is economic hardship on the part of the mother."). 
calls the problem of sexual harassment in the workplace "virtually epidemic." There are no laws that prohibit such behavior. ${ }^{93}$ A severe shortage of housing also acts to curtail women's options. Indeed, the lack of affordable housing is so severe that it is common for couples to remain living together in the same apartment following a divorce. ${ }^{94}$ The housing crisis may amplify a woman's desperation by limiting her options in the event that she seeks to leave an unhappy or violent relationship.

Unfortunately, in spite of its commitment to building an egalitarian, democratic society, violence against Hungarian women remains relatively commonplace. ${ }^{95}$ Women seeking to exit violent relationships must do so without the assistance of legal restraining orders, which do not exist. Furthermore, there are few shelters available in the country. ${ }^{96}$ In order to initiate legal action against an abusive spouse, a woman must have proof of injury, which requires a special medical examination that costs US\$8.50. ${ }^{97}$ Finally, judicial response to domestic violence tends to be unsympathetic, as judges attempt to evaluate whether the abuse was "in proportion to the behavior of the wife." 98 Again, these facts do not necessarily cause maternal filicide, but they certainly help to illustrate the limited scope of alternatives for a woman who feels unsafe in her relationship. A final underlying factor in understanding maternal filicide is Hungary's treatment of sexual assault. Rape, with its obvious connection to unwanted pregnancy, is viewed as a private crime, rather than a public offense, and thus, it is up to the survivor to instigate any prosecution. In rape prosecutions, the survivor's behavior is considered a material element, and any "imprudent or careless" behavior is regarded as a mitigating circumstance. ${ }^{99}$ The age of consent is 14 , so that this high evidentiary burden is applied to relatively young adolescent victims, as well as to adult women. This law opens Hungarian adolescents to sexual coercion and exploitation, and the high evidentiary burdens, in addition to the requirement that the teen initiate the prosecution on her own, virtually insure that the perpetrators will go unpunished.

The absence of any scholarly analysis of maternal filicide in Hungary renders highly speculative any effort to ascertain the causes of this crime. Nonetheless, circumstances

93 Country Report-Hungary, supra note 81.

94 Women of the World, supra note 75, at 64.

95 Hungary's Constitution states that the country "accepts the generally recognized principles of international law, and shall harmonize the country's domestic law with the obligations assumed under international law." Hungary ratified the United Nation's Convention on the Elimination of All Forms of Discrimination Against Women (CEDAW) in 1980. Women of the World, supra note 75, at 53. Women Against Violence, an NGO reported that one woman is beaten to death each week, while $20 \%$ of women are threatened by or victims of domestic violence. Country Report-Hungary, supra note 81.

96 Country Report-Hungary, supra note 81, and Women of the World, supra note 75, at 66.

97 Women of the World, supra note 75 , at 67.

98 Judges are unsympathetic to domestic violence because they accept the beatings of women and children as normal. For example, one court categorized a relationship between a husband and a wife as "average" after the husband nearly stabbed his wife to death. Moreover, while men are sentenced to 2 to 4 years on average when a domestic dispute results in the death of his wife, women are routinely sentenced to 6 to 7 years for the killing their spouse. Courts justify this dispartity with the ill-conceived proposition that the woman should have left her husband instead of killing him. Women of the World, supra note 75, at 67.

99 Women of the World, supra note 75, at 66. 
suggest that women and girls in Hungary experience a relatively limited amount of reproductive and sexual autonomy. Hungarians have recognized the link between limited access to sex education and contraception and higher abortion rates, particularly for teens. ${ }^{100}$ What they have yet to explore is the extent to which existing socio-economic realities for women, such as the lack of affordable housing, and the barriers to prosecuting rape and domestic violence, might affect a woman's experience of motherhood. Hungary is learning that simply setting legal limits on abortion does not necessarily result in higher birth rates. The relatively high prevalence of maternal filicide suggests that at least some women are so resistant to becoming mothers that they are willing to resort to desperate means to prevent this from happening.

\section{Lessons and policy directives}

This brief overview of cross-cultural patterns in maternal filicide gives rise to several observations. First, it is critical to note the incomplete nature of the available information on maternal filicide. Perhaps this is because of the conundrum that underlies Henri Bergson's remark that "The eye sees only that which the mind is prepared to comprehend." Motherhood is conceived of as the last bastion of safety in a troubled world. It is profoundly disconcerting to expose the myths and limits of this notion. As a result, when societies begin to acknowledge the existence of maternal filicide, they do so tentatively, limiting discussion to the forms of maternal filicide that seem to be most readily understood and might be traced to concrete causes. For example, tracing neonaticide in Hungary to Hungarian policies on contraception and abortion. It is much too frightening to consider the possibility that there may be something toxic in the norms that shape women's lives in general, and motherhood in particular, and that this may contribute to some women's willingness to kill their children.

Government responses to maternal filicide reflect this blinkered approach to the problem. It is widely understood that motherhood, particularly with young children, can be experienced as stressful. There is ample evidence that social support for mothers, including adequate mental health interventions, are associated with greater life satisfaction and a significant improvement in the mental health of mothers and children. ${ }^{101}$ Nonetheless, it seems that there is little effort, at the governmental level, toward developing comprehensive social support programs for new mothers. In the United States, the predominant response to maternal filicide is a tendency toward severe punishment of the individual defendant. This tendency to blame

100 See Tamas S. Kiss, Teenagers in Trouble, Budapest Sun, Oct. 5, 2002 (focusing on the need sex education and availability of contraception for adolescents), Sazmosi, supra note 77 (noting that young people are most affected by the National Health Fund's refusal to subsidize contraception), and New Teen Clinics Open to Combat Abortion, Budapest Sun, May 20, 1999 (blaming high teen pregnancy rate on lack of sex education and noting that $10 \%$ of abortions performed in Hungary were on teenagers).

101 See A.D. Cox, Befriending Young Mothers, 163 Brit.J. Psychiatry 6 (1993); Faith L. Parker, Chaya S. Piotrkowski, Lenore Peay, Head Start as a Social Support for Mothers: The Psychological Benefits of Involvement, 57 Amer. J. Orthopsychiat. 220 (1987); Sharon Telleen, Allen Herzog, Theresa L. Kilbane, Impact of a Family Support Program on Mothers' Social Support and Family Stress, 59 Amer. J. Orthopsychiat. 410 (1989). 
the individual seems to displace any effort to see her actions as part of a pattern, let alone as part of a societal ill. In India, there are ongoing efforts made at banning prenatal screening, but little consideration of the deep-seated issues that drive mothers to seek out this screening. As one Hungarian professional responded, when asked about the likely success of using incubators to encourage mothers to drop off their unwanted children, and stricter penalties to punish those who abandoned them elsewhere, such limited responses to the problem of neonaticide show that "no one was really interested in what makes a woman choose to murder." 102

Therein lies the central task for those who seek to eliminate maternal filicide: it begins with understanding the lives of those who commit this crime. Only when we come face to face with the desperation of these mothers can we begin to devise effective manners of protecting both them and their children.

102 Sazmosi, supra note 77 (quoting child psychologist, Gabor Takacs). 